\title{
Clonal haematopoiesis and cardiovascular diseases: A growing relationship
}

Abbreviated title: Clonal haematopoiesis and cardiovascular diseases

Tweet: This review aims to present a state of knowledge about links between clonal hematopoiesis of indeterminate potential and cardiovascular diseases, and the changes we can expect in our practice

Sami Fawaz ${ }^{\mathrm{a}}$, Olivier Mansier ${ }^{\mathrm{b}, \mathrm{c}}$, Yann Pucheu ${ }^{\mathrm{a}, \mathrm{c}}$, Séverine Marti ${ }^{\mathrm{b}}$, Harmony Leroy ${ }^{\mathrm{b}, \mathrm{c}}$, Astrid Gaufroy $^{\mathrm{a}}$, Jean Broitman ${ }^{\mathrm{a},}$, Chloe James ${ }^{\mathrm{b}, \mathrm{c}}$, Thierry Couffinhal ${ }^{\mathrm{a}, \mathrm{c}, *}$

a Centre d'Exploration, de Prévention et de Traitement de l'Athérosclérose (CEPTA), CHU Bordeaux, 33000 Bordeaux, France

' Laboratoire d'Hématologie, CHU Bordeaux, 33000 Bordeaux, France

' Biologie des Maladies Cardiovasculaires - U1034, INSERM, Université de Bordeaux, 33600

Pessac, France

* Corresponding author at: Centre d'Exploration, de Prévention et de Traitement de l'Athéroclérose, CEPTA, Hôpital Cardiologique du Haut-Lévêque, Avenue de Magellan 33604 Pessac CEDEX, France.

E-mail address: thierry.couffinhal@inserm.fr (T. Couffinhal).

Twitter address: @iCouffi 


\section{Summary}

Cardiovascular diseases, particularly atherothrombosis, are the leading cause of death worldwide, but their mechanisms are not yet fully understood. Traditional cardiovascular risk factors have been known for many years, but are not enough to predict individual risk. Clonal haematopoiesis of indeterminate potential (CHIP) has been described recently; it corresponds to the clonal expansion of a population of haematopoietic cells in response to the acquisition of a somatic mutation, without any clinical or biological sign of haematological malignancy. The prevalence of this condition increases with age, reaching $10-20 \%$ of the general population aged $>70$ years. Recent observational studies have shown a link between CHIP and cardiovascular diseases in humans, revealing that CHIP carriers have a higher risk of myocardial infarction, heart failure and severe aortic valve stenosis. The prognosis of these conditions also seems to be altered by the presence of CHIP. Experimental studies have identified that the immune system and inflammation - particularly interleukin-1 $\beta$-secreting macrophages - play a critical role in enhancing the cardiovascular consequences of $\mathrm{CHIP}$, through their action on the atherosclerotic plaque and myocardial tissues. We aimed to write an extensive review of what is currently known about CHIP and its cardiovascular consequences, the pathophysiological mechanisms leading to the increased cardiovascular risk and, finally, the expected influence on our daily practice and how we care for patients with CHIP.

\section{Résumé}

Les maladies cardiovasculaires, en particulier l'athérosclérose, sont la principale cause de décès dans le monde, mais leur pathogénie n'est pas encore complètement élucidée. En effet, les facteurs de risque cardiovasculaires traditionnels sont bien connus depuis de nombreuses années mais ne suffisent pas à prédire le risque individuel. L'hématopoïèse clonale de potentiel indéterminé (CHIP) a été décrite récemment. Elle correspond à l'expansion clonale d'une population de cellules hématopoïétiques en réponse à l'acquisition d'une mutation somatique, sans aucun signe clinique ou biologique d'hémopathie maligne. La prévalence de cette affection augmente avec l'âge, pour atteindre $10-20 \%$ de la population générale de plus de 70 ans. De récentes études observationnelles ont montré un lien entre la CHIP et les maladies cardiovasculaires chez l'homme, révélant que les porteurs de CHIP avaient plus de risque d'infarctus du myocarde, d'insuffisance cardiaque ou de rétrécissement aortique serré. Le pronostic de ces pathologies semble également être grevé par la 
présence d'une CHIP. Des études expérimentales ont par la suite mis en lumière le rôle crucial du système immunitaire et de l'inflammation, en particulier des macrophages produisant de l'interleukine$1 \beta$, pour expliquer les conséquences cardiovasculaires de la CHIP, à travers leur action sur la plaque d'athérome et les tissus myocardiques. Notre objectif était d'écrire une revue approfondie de ce qui est connu actuellement sur la CHIP et ses conséquences cardiovasculaires, les mécanismes physiopathologiques conduisant au sur-risque cardiovasculaire, et enfin l'influence attendue sur notre pratique quotidienne et la façon dont nous prenons soin des patients porteurs de CHIP.

\section{KEYWORDS}

Haematopoiesis;

Cardiovascular diseases;

Risk factors;

Inflammation;

Atherosclerosis

\section{MOTS CLÉS}

Hématopoïèse ;

Maladies cardiovasculaires ;

Facteurs de risque ;

Inflammation ;

Athérosclérose

Abbreviations: CHIP, clonal haematopoiesis of indeterminate potential; CVD, cardiovascular disease; DNA, deoxyribonucleic acid; HSC, haematopoietic stem cell; hSCRP, high-sensitivity Creactive protein; IL, interleukin; NLRP3, nucleotide-binding oligomerization domain-like receptor family pyrin domain containing 3; TAVI, transcatheter aortic valve replacement; VAF, variant allelic fraction. 


\section{Background}

Atherothrombosis is the main cause of death worldwide. Although our knowledge and ability to treat patients has improved in recent years, some aspects of the disease remain unclear. We know from our daily practice that people without any traditional cardiovascular risk factors can experience cardiovascular events. Furthermore, within a group of people of the same age bearing the same cardiovascular risk factors, some will experience myocardial infarction and others will not. Thus, traditional risk factors account for only $75-80 \%$ of events associated with cardiovascular disease (CVD) [1]. This underscores the need to identify other contributing factors to enhance our understanding of the disease and improve strategies for both treatment and prevention.

A new concept has emerged recently, which places the role of the haematopoietic system at the centre of this investigation. Here we provide a review of the current state of knowledge about clonal haematopoiesis of indeterminate potential (CHIP), its link with CVD, and the potential implications for our daily practice, both current and future.

\section{CHIP}

A somatic mutation is a genetic alteration acquired by a cell that can be passed to the progeny of the mutated cell during the course of cell division. Somatic mutations differ from germ-line mutations, which are inherited genetic alterations that occur in the germ cell.

Somatic mutations accumulate in normal tissues as a function of time. The majority of these mutations have no effect on cell behaviour, so selection does not act upon them. Rarely, a mutation will arise that confers a growth advantage to the cell in which it occurs. Such a mutation would allow that cell and its progeny, referred to as a "clone," to expand progressively over time. This is now known to occur in a number of tissues, particularly in elderly individuals. When this happens in a haematopoietic stem cell (HSC), a condition known as "clonal haematopoiesis" appears as the result of the contribution of the mutated clone to the production of a substantial proportion of mature blood cells (Fig. 1). Clonal haematopoiesis is well known in the scope of haematological malignancies as being a step towards overt neoplasms, such as acute myeloid leukaemias, when the somatic mutation involves a leukaemia driver gene.

CHIP was described several years ago, and is defined by the clonal expansion of a haematopoietic cell population in response to the acquisition of a leukaemia driver gene mutation, at a 
variant allelic fraction $(\mathrm{VAF}) \geq 2 \%$, without any biological or clinical sign of haematological malignancy [2]. Mutations observed in CHIP frequently involve epigenetic regulators, the main ones being DNMT3A, TET2 and ASXL1 (Table 1) [3]. Because these somatic mutations do not significantly disturb cell differentiation, mutated mature cells are produced as normal cells, and circulate in the peripheral blood. Thus, during this premalignant state, patients have totally normal blood cell counts. The involvement in CHIP of the JAK2 ${ }^{\mathrm{V} 617 \mathrm{~F}}$ mutation, which is known for being involved in myeloproliferative neoplasms, is a matter of debate [4-6].

\section{How to detect CHIP}

Because the acquired mutation is present in mature blood cells, detecting CHIP is feasible in deoxyribonucleic acid (DNA) from circulating leukocytes from a blood sample. A bone marrow test is not necessary. Next-generation sequencing has been used as the reference technique for genomic DNA sequencing for almost a decade; its cost has decreased rapidly over the last few years, currently allowing the entire genome to be sequenced in a few days for approximately $€ 1000$. However, wholegenome sequencing is a suboptimal technique to search for CHIP because of its lack of sensitivity. As CHIP is defined as the presence of a mutation with a VAF $\geq 2 \%$, more than 500 DNA molecules would need to be analysed to obtain reliable results for a given gene. To date, such a sequencing depth cannot be achieved easily using whole-genome or even whole-exome sequencing.

Many genes have been identified as being involved in CHIP. However, most of the time, a patient with CHIP has only one mutation. Moreover, only some of these mutations have been identified as mutated recurrently in CHIP, and are detected in $>90 \%$ of CHIP carriers (Table 1 ). The three most frequently mutated genes (TET2, DNMT3A and ASXL1) represent $>70 \%$ of CHIP cases. Thus, restricting sequencing analysis to a panel of genes is a worthwhile strategy for detecting CHIP. Indeed, by limiting the genomic regions analysed, targeted sequencing allows the depth of sequencing to be increased, thus improving the ability to detect CHIP with low-VAF mutations. Such a strategy also reduces the cost and time of analysis. In this way, CHIP could be detected in routine practice in a week for less than €100.

\section{Prevalence}


In 2014, two studies evaluated the prevalence of individuals presenting with CHIP (Fig. 2) [7, 8]. When analysing blood samples, CHIP seems to be rare before the age of 40 years; its prevalence then increases with age, with an estimated frequency of $5 \%$ at 60 years, and reaching $10-20 \%$ of those aged $>70$ years. Recently, Busque et al. studied a population with a mean age of 75 years, and found that 23\% of the cohort had CHIP [9]. Some authors reported a higher prevalence of CHIP in healthy individuals (40\% after 50 years of age) when detecting mutations in the bone marrow with a sensitivity threshold of $1 \%[10]$.

\section{CHIP and haematological malignancy}

Although Jaiswal et al. demonstrated that CHIP carriers had an 11-fold increased risk of developing haematological malignancies (myelodysplastic syndromes, acute leukaemias or even lymphomas), the absolute risk of evolving to a haematological cancer remains low (about 1\% per year).

\section{CHIP links to CVD (Table 2)}

\section{Atherothrombosis}

Surprisingly, when Jaiswal et al. looked at the prognosis of CHIP carriers in 2014, they found that in addition to an increased risk of haematological malignancies, they had an increased risk of overall mortality [8]. This increased mortality was driven primarily by increased cardiovascular-related mortality, and - interestingly - not deaths resulting from cancer. In this study, the risk of cardiovascular ischaemic events was increased by a factor of 2 , and the risk of ischaemic stroke by a factor of 2.6. Because of these surprising results, the same team tested the hypothesis that CHIP is correlated to CVD. They chose two cohorts of people with mean ages of 60 and 70 years, bearing cardiovascular risk factors, and followed them for several years; they found a twofold increase in the risk of coronary artery disease in CHIP carriers compared with non-CHIP carriers [11]. Interestingly, in two additional cohorts of people aged $<50$ years, they found a fourfold increase in early onset myocardial infarction in those who presented with CHIP [11]. Additionally, there was a significant increase in the coronary artery calcium score evaluated by computed tomography in CHIP carriers: compared with non-carriers, CHIP carriers had a threefold increased risk of having a coronary artery calcium score $>615$ Agatston units, which identifies those at highest risk of coronary artery disease [7, 11]. 
These observations raise the question of how much influence CHIP has in the development of CVD, when compared with traditional risk factors, such as smoking, hypertension, dyslipidaemia, diabetes or family history of CVD. Jaiswal and Libby thus studied the weight of each factor in the development of CVD, based on previous cohorts, and found that the presence of CHIP could be one of the strongest factors associated with CVD, conferring a higher relative risk than smoking, hypertension and dyslipidaemia [12]. However, some questions remain. It is still not known whether CHIP is an independent risk factor or if its presence potentiates existing ones, increasing the risk of CVD developing in people harbouring traditional risk factors.

\section{Heart failure and valvular heart disease}

CHIP made an entrance into the world of CVD through the study of atherosclerotic CVD, but the association is likely to be much deeper. Dorsheimer et al. studied the prevalence and prognosis of CHIP in a population of 200 patients with chronic heart failure, with a mean age of 65 years [13]. The team found an increased prevalence of CHIP in this population compared with what is described in the general population, with more than $18 \%$ of the total cohort harbouring CHIP $[7,8,14]$. This increased prevalence was constant in each age category, with a more than twofold increase in all groups.

Consistent with previous data in the general population, DNMT3A and TET2 were the two genes most affected by somatic mutations. CHIP carriers appeared to have a significantly worse prognosis than non-carriers regarding both death and hospitalization for heart failure. Indeed, $37 \%$ of patients harbouring CHIP died during a 4-year follow-up period, versus $24 \%$ of those who did not have CHIP. The risk of death combined with rehospitalization for heart failure was multiplied by a factor of 3 . Interestingly, there seemed to be a dose-response effect between a poor prognosis and the clone size estimated by the VAF.

More recently, Mas-Peiro et al. studied the prevalence and prognosis of patients harbouring CHIP among a population with a mean age of 83 years undergoing transcatheter aortic valve replacement (TAVI) for the treatment of degenerative aortic valve stenoses [15]. They found a higher prevalence of CHIP in this population than in healthy controls, with approximately $33 \%$ of the TAVI group harbouring a mutation in DNMT3A or TET2 (the only two genes studied) at a VAF $\geq 2 \%$. Similar to the general population, the prevalence seemed to increase with age, from $25 \%$ in patients between the ages of 55 and 69 years, to more than $52 \%$ in those aged $>90$ years. Again, as in atherosclerotic 
CVD and heart failure, the prognosis seemed to be worse in the presence of a candidate driver gene mutation. Over an 8-month follow-up period, it was found that CHIP carriers had a fourfold increase in their risk of death.

Taken together, these observations strongly suggest that clonal haematopoiesis may play a role in the development of different CVDs.

\section{How does CHIP increase cardiovascular risk?}

\section{Experimental approaches}

In 2017, Fuster et al. evaluated the role of TET2 mutations in the development of atherosclerosis in mice [16]. Using a mouse model in which $10 \%$ of HSCs were inactivated for TET2, they observed an amplification of blood cells bearing the TET2 mutation, as well as a marked increase in atherosclerotic burden, with a $60 \%$ increased thickness of the atherosclerotic plaques in the aortic root compared with control mice. This finding is consistent with the results of a study conducted by Jaiswal et al. in the same year, which reported that mice bearing a homozygous mutation of TET2 showed an increase in atherosclerotic lesions of the aorta, from 1.4-fold in the aortic root to 2.7 -fold in the descending aorta compared with control mice [11].

Both studies showed that macrophages, which populated the plaques and harboured the mutation, had enhanced inflammatory activity, producing more cytokines, particularly interleukin (IL)$1 \beta$. Of note, Fuster et al. showed that this overproduction could be explained by an increase in activity of the nucleotide-binding oligomerization domain-like receptor family pyrin domain containing 3 (NLRP3) inflammasome, an intracellular oligomeric protein complex that cleaves the pro-IL-1 $\beta$ into IL$1 \beta$ (Fig. 3) [16].

Other studies have focused on mechanisms underlying the relationship between CHIP and heart failure. Sano et al. demonstrated in both ischaemic and non-ischaemic heart failure models that TET2 mutations were associated with adverse remodelling, a decrease in left ventricular ejection fraction and an increase in left ventricular systolic and diastolic volumes, as well as larger areas of fibrosis in the marginal zone [17]. As for atherosclerosis, this phenomenon was linked with greater macrophage infiltration in the marginal zone, and the expression of various proinflammatory cytokines and chemokines, including IL-1 $\beta$. In the same year, Sano et al. also demonstrated in another heart 
failure model that $D N M T 3 A$ mutations were responsible for a similar proinflammatory phenotype of mutated myeloid cells [18].

In summary, these studies support the hypothesis that TET2 and DNMT3A mutations confer an advantage to mutated cells, as well as a proinflammatory phenotype, responsible for enhanced recruitment of leukocytes to cardiovascular tissues, and leading to the development of atherosclerosis or heart failure (Central illustration). This deleterious phenotype involves the NLRP3 inflammasome, which could represent a therapeutic target in various CVDs linked to CHIP. By comparison, little is known about the pathophysiology linking other CHIP-associated mutations to cardiovascular complications.

\section{Human data}

Although studies conducted in a mouse model have suggested that CHIP triggers an inflammatory state, few studies have been conducted in humans to verify this hypothesis. High-sensitivity CRP (hsCRP) has been used as a predictor of cardiovascular events for many years, as it reflects the patient's inflammatory state and their susceptibility to plaque rupture [19]. In a recent study, Busque et al. suggested that CHIP carriers had slightly higher concentrations of hsCRP than non-carriers [9]. Mas-Peiro et al. also speculated that CHIP was associated with a proinflammatory state in patients [15]. Thus, TET2 mutations would be linked to an increase in the frequency of inflammatory monocytes known to be involved in atherosclerosis development, whereas DNMT3A mutations would favour a proinflammatory polarization of T lymphocytes.

\section{Implications for clinical practice}

\section{What is the place for CHIP detection in the management of CVD?}

Despite accumulating data, clonal haematopoiesis still needs to be validated as a full-fledged cardiovascular risk factor. To do this, observational studies are needed to reassess the prevalence of CHIP in the general population, as well as in patient populations seen in cardiology clinics worldwide. These studies should seek to confirm the link between the presence of CHIP, a higher inflammation level and a more pronounced atheroma volume.

The medical community will need to assess the best way to include CHIP in daily practice. The first question is how to select patients for CHIP screening. We could focus on patients who have a 
cardiovascular event without a high level of risk, based on traditional risk factors. This would allow us to better understand why the event happened, and give us tools to improve prevention of a recurrence alongside standard care. Another interesting population to screen could be patients with high concentrations of hsCRP, because they may represent a population with a high prevalence of CHIP. In order to let inflammation decrease and avoid an overestimation as a result of the acute cardiovascular event, hsCRP can be measured a few months after the event, when inflammation comes back to its basal level [20]. Finally, we could propose screening of patients presenting with a severe atheroma load, such as cases of multitroncular coronary artery disease or extensive peripheral artery disease. Screening for CHIP in the scope of primary prevention will be central in the future, if $\mathrm{CHIP}$ is verified as a risk factor with as much weight as smoking or dyslipidaemia in the development of CVD. Given that CHIP could have a synergistic action with other traditional cardiovascular risk factors, it will be important to adjust current guidelines to account for this risk.

We have seen that screening for CHIP can be quite easy to perform in practice. It can fit to standard care requirements, in that the material is simple to get via a standard blood sample, the results are available within a few days and the costs are decreasing to the point where they will likely become affordable for routine practice.

The identification of CHIP in our daily practice will then raise the question of how to treat these patients.

\section{Anti-inflammatory therapies}

Recent studies have tested the hypothesis that anti-inflammatory molecules could improve the prognosis of people with CVD. In 2017, Ridker et al. studied the effect of canakinumab, a human monoclonal antibody targeting IL-1 $\beta$, in a population of patients with a history of myocardial infarction who had an hsCRP blood concentration of $\geq 2 \mathrm{mg} / \mathrm{L}$ [21]. The team showed a decrease in the risk of cardiovascular deaths, non-fatal myocardial infarctions and non-fatal strokes in patients treated with the highest doses of canakinumab after nearly 4 years of follow-up. Canakinumab significantly decreased hsCRP blood concentrations. Interestingly, a subgroup analysis showed a trend towards a reduction in the risk of hospitalization for heart failure and heart failure-related mortality in patients who were receiving canakinumab [22]. These data suggest that targeting IL-1 $\beta$ and reducing the degree of 
inflammation may be an efficient way to reduce the risk of adverse cardiac events in secondary prevention.

Although canakinumab seems interesting in the prevention of CVD in patients at risk, it is not yet an approved treatment or used routinely in cardiology. Another study therefore evaluated the benefit of a widely used anti-inflammatory therapy - colchicine [23]. This drug is known to reduce inflammation through various mechanisms, in particular interference with NLRP3 inflammasome, resulting in reduction of IL-1 $\beta$ release, which in turn reduces the production of various cytokines and proinflammatory molecules, such as IL-6, tumour necrosis factor $\alpha$ and C-reactive protein [24]. In the COLCOT trial, Tardif et al. compared the effect of colchicine or placebo on prognosis in patients who had recently had a myocardial infarction. The authors showed a significant reduction in major adverse cardiovascular events, mainly driven by a decrease in the risk of stroke and the need for urgent coronary revascularization.

These data demonstrate the beneficial effect of targeting the immune system and reducing inflammation to prevent CVD. CHIP would be responsible for a low-grade inflammation that could favour CVD. Therefore, we can speculate that the efficacy of anti-inflammatory drugs could be mainly driven by an effect on CHIP carriers, not yet identified in these studies, who could be more receptive because of their proinflammatory state [25]. While we wait for more specific treatments, antiinflammatory therapies may be one way to properly treat patients with CHIP.

\section{Conclusions}

CHIP is a common condition, particularly in the elderly, and is associated with an increased risk of CVD. Recent studies have suggested its implication in the pathogenicity of CVD, and models have shown that inflammation and dysregulation of the immune system are at the core of this involvement. As our knowledge grows, development of specific treatments will be a goal in order to move towards more personalized care and improve prevention of CVD.

\section{Sources of funding}

None.

\section{Disclosure of interest}


The authors declare that they have no conflicts of interest concerning this article. 


\section{References}

[1] Berry JD, Dyer A, Cai X, et al. Lifetime risks of cardiovascular disease. N Engl J Med 2012;366:321-9.

[2] Steensma DP, Bejar R, Jaiswal S, et al. Clonal hematopoiesis of indeterminate potential and its distinction from myelodysplastic syndromes. Blood 2015;126:9-16.

[3] Jaiswal S, Ebert BL. Clonal hematopoiesis in human aging and disease. Science 2019;366:eaan4673.

[4] Cassinat B, Harrison C, Kiladjian JJ. Clonal Hematopoiesis and Atherosclerosis. N Engl J Med 2017;377:1400-1.

[5] Jaiswal S, Natarajan P, Ebert BL. Clonal Hematopoiesis and Atherosclerosis. N Engl J Med 2017;377:1401-2.

[6] Phillips R, Chaudry S, Chevassut T. Clonal Hematopoiesis and Atherosclerosis. N Engl J Med 2017;377:1401.

[7] Genovese G, Kahler AK, Handsaker RE, et al. Clonal hematopoiesis and blood-cancer risk inferred from blood DNA sequence. N Engl J Med 2014;371:2477-87.

[8] Jaiswal S, Fontanillas P, Flannick J, et al. Age-related clonal hematopoiesis associated with adverse outcomes. N Engl J Med 2014;371:2488-98.

[9] Busque L, Sun M, Buscarlet M, et al. High-sensitivity C-reactive protein is associated with clonal hematopoiesis of indeterminate potential. Blood Adv 2020;4:2430-8.

[10] Guermouche H, Ravalet N, Gallay N, et al. High prevalence of clonal hematopoiesis in the blood and bone marrow of healthy volunteers. Blood Adv 2020;4:3550-7.

[11] Jaiswal S, Natarajan P, Silver AJ, et al. Clonal Hematopoiesis and Risk of Atherosclerotic Cardiovascular Disease. N Engl J Med 2017;377:111-21.

[12] Jaiswal S, Libby P. Clonal haematopoiesis: connecting ageing and inflammation in cardiovascular disease. Nat Rev Cardiol 2020;17:137-44.

[13] Dorsheimer L, Assmus B, Rasper T, et al. Association of Mutations Contributing to Clonal Hematopoiesis With Prognosis in Chronic Ischemic Heart Failure. JAMA Cardiol 2019;4:2533.

[14] Zink F, Stacey SN, Norddahl GL, et al. Clonal hematopoiesis, with and without candidate driver mutations, is common in the elderly. Blood 2017;130:742-52. 
[15] Mas-Peiro S, Hoffmann J, Fichtlscherer S, et al. Clonal haematopoiesis in patients with degenerative aortic valve stenosis undergoing transcatheter aortic valve implantation. Eur Heart J 2020;41:933-9.

[16] Fuster JJ, MacLauchlan S, Zuriaga MA, et al. Clonal hematopoiesis associated with TET2 deficiency accelerates atherosclerosis development in mice. Science 2017;355:842-7.

[17] Sano S, Oshima K, Wang Y, et al. Tet2-Mediated Clonal Hematopoiesis Accelerates Heart Failure Through a Mechanism Involving the IL-1beta/NLRP3 Inflammasome. J Am Coll Cardiol 2018;71:875-86.

[18] Sano S, Oshima K, Wang Y, Katanasaka Y, Sano M, Walsh K. CRISPR-Mediated Gene Editing to Assess the Roles of Tet2 and Dnmt3a in Clonal Hematopoiesis and Cardiovascular Disease. Circ Res 2018;123:335-41.

[19] Rifai N, Ridker PM. High-sensitivity C-reactive protein: a novel and promising marker of coronary heart disease. Clin Chem 2001;47:403-11.

[20] Lafitte $M$, Tastet $S$, Perez $P$, et al. High sensitivity $C$ reactive protein, fibrinogen levels and the onset of major depressive disorder in post-acute coronary syndrome. BMC Cardiovasc Disord $2015 ; 15: 23$

[21] Ridker PM, Everett BM, Thuren T, et al. Antiinflammatory Therapy with Canakinumab for Atherosclerotic Disease. N Engl J Med 2017;377:1119-31.

[22] Everett BM, Cornel JH, Lainscak M, et al. Anti-Inflammatory Therapy With Canakinumab for the Prevention of Hospitalization for Heart Failure. Circulation 2019;139:1289-99.

[23] Tardif JC, Kouz S, Waters DD, et al. Efficacy and Safety of Low-Dose Colchicine after Myocardial Infarction. N Engl J Med 2019;381:2497-505.

[24] Slobodnick A, Shah B, Pillinger MH, Krasnokutsky S. Colchicine: old and new. Am J Med 2015;128:461-70.

[25] Svensson EC, Madar A, Campbell CD, et al. TET2-Driven Clonal Hematopoiesis Predicts Enhanced Response to Canakinumab in the CANTOS Trial: An Exploratory Analysis. Circulation 2018;136(Suppl-_1):A15111. 
Figure legends

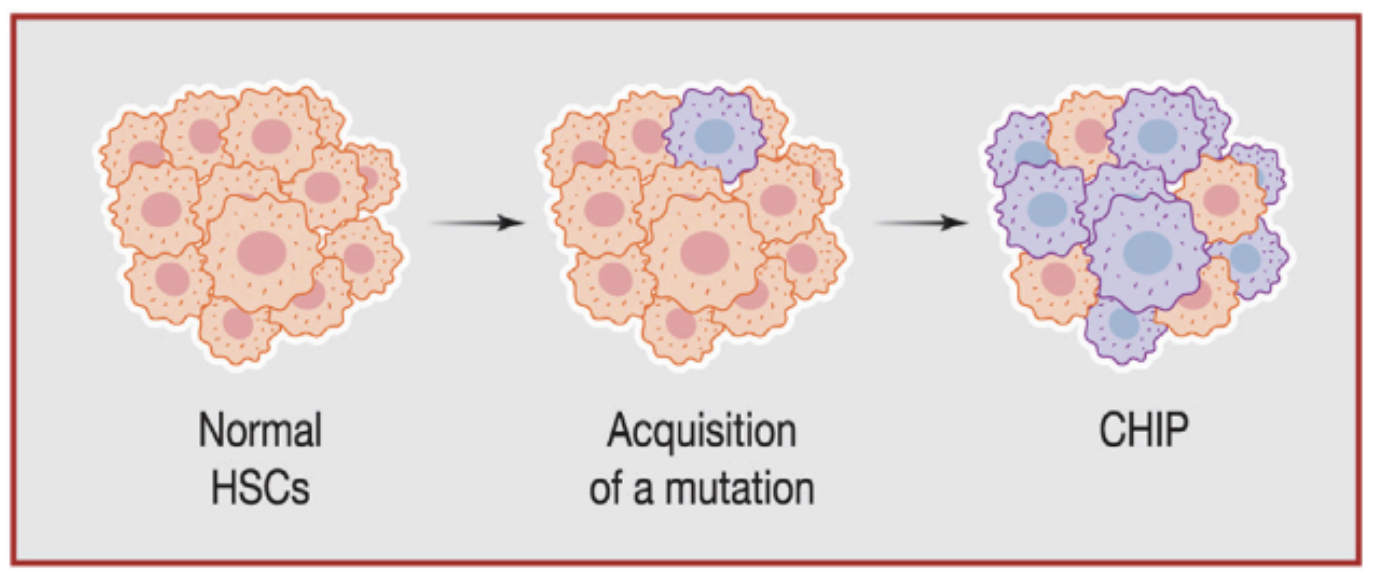

Figure 1. Generation of a clone. In the bone marrow, a haematopoietic stem cell (HSC) acquires a somatic mutation in a leukaemia driver gene, conferring to its lineage a growth advantage leading to clonal expansion. CHIP: clonal haematopoiesis of indeterminate potential. 


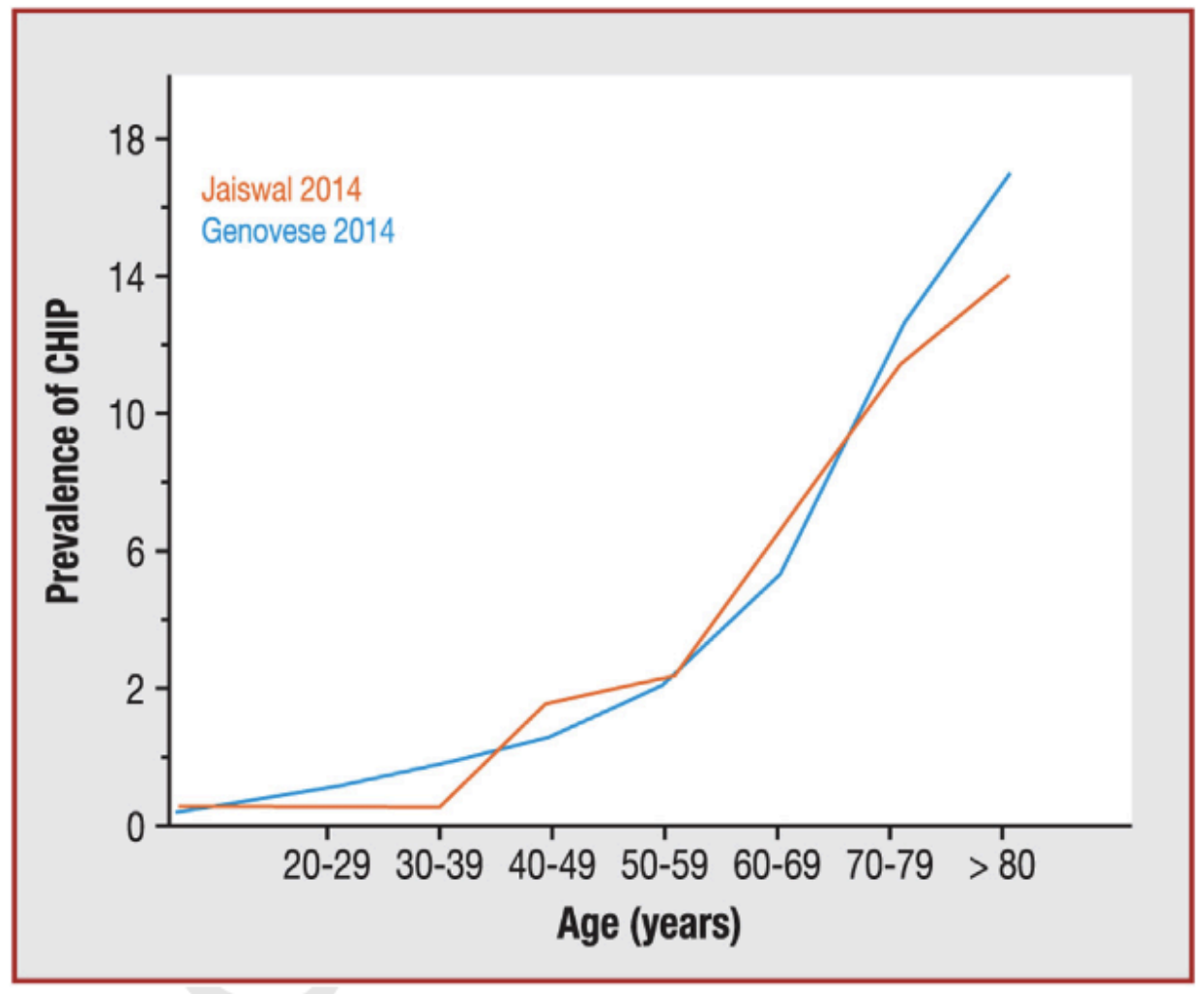

Figure 2. Prevalence of clonal haematopoiesis of indeterminate potential (CHIP) according to studies. 


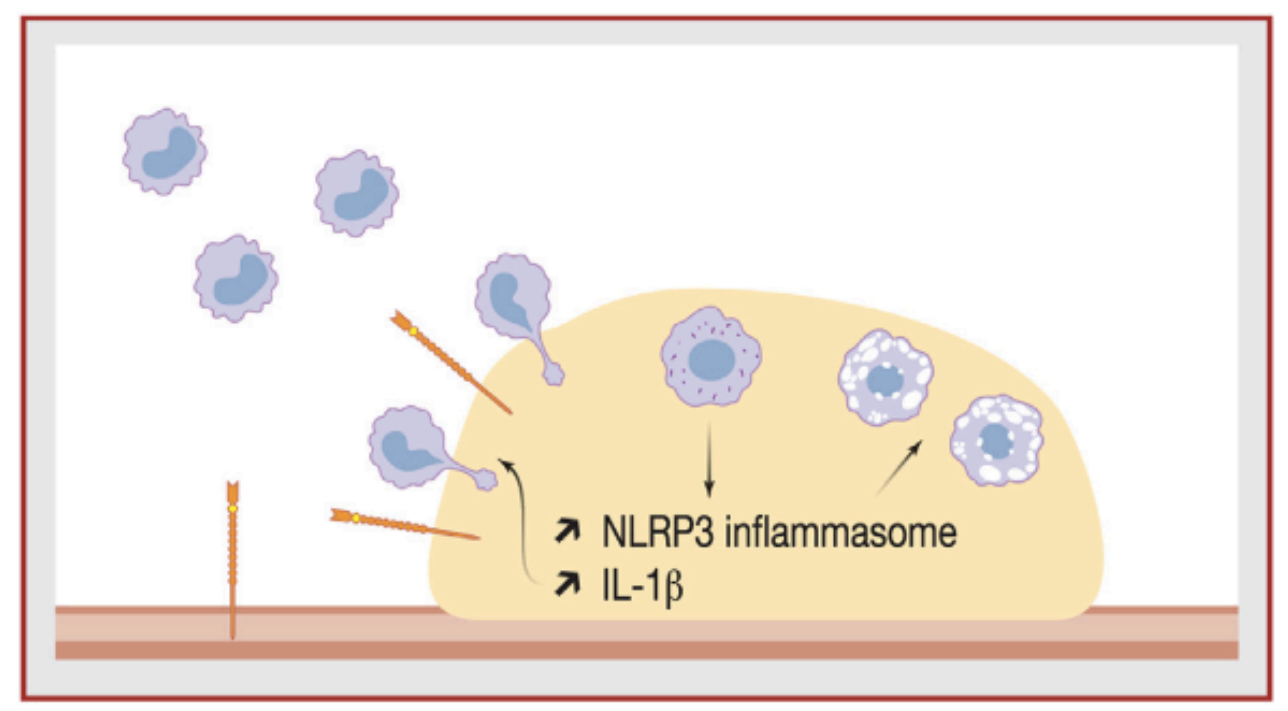

Figure 3. Clonal haematopoiesis of indeterminate potential increases atherothrombosis. Circulating mutated monocytes migrate to the atherosclerotic plaque, switching to macrophages. Mutated cells overproduce interleukin (IL)- $1 \beta$ because of excessive activation of the nucleotide-binding oligomerisation domain-like receptor family pyrin domain containing 3 (NLRP3) inflammasome, which increases phagocytosis and production of foam cells and recruitment of monocytes by overexpression of adhesion molecules (P-selectin), enhancing atherothrombosis. 


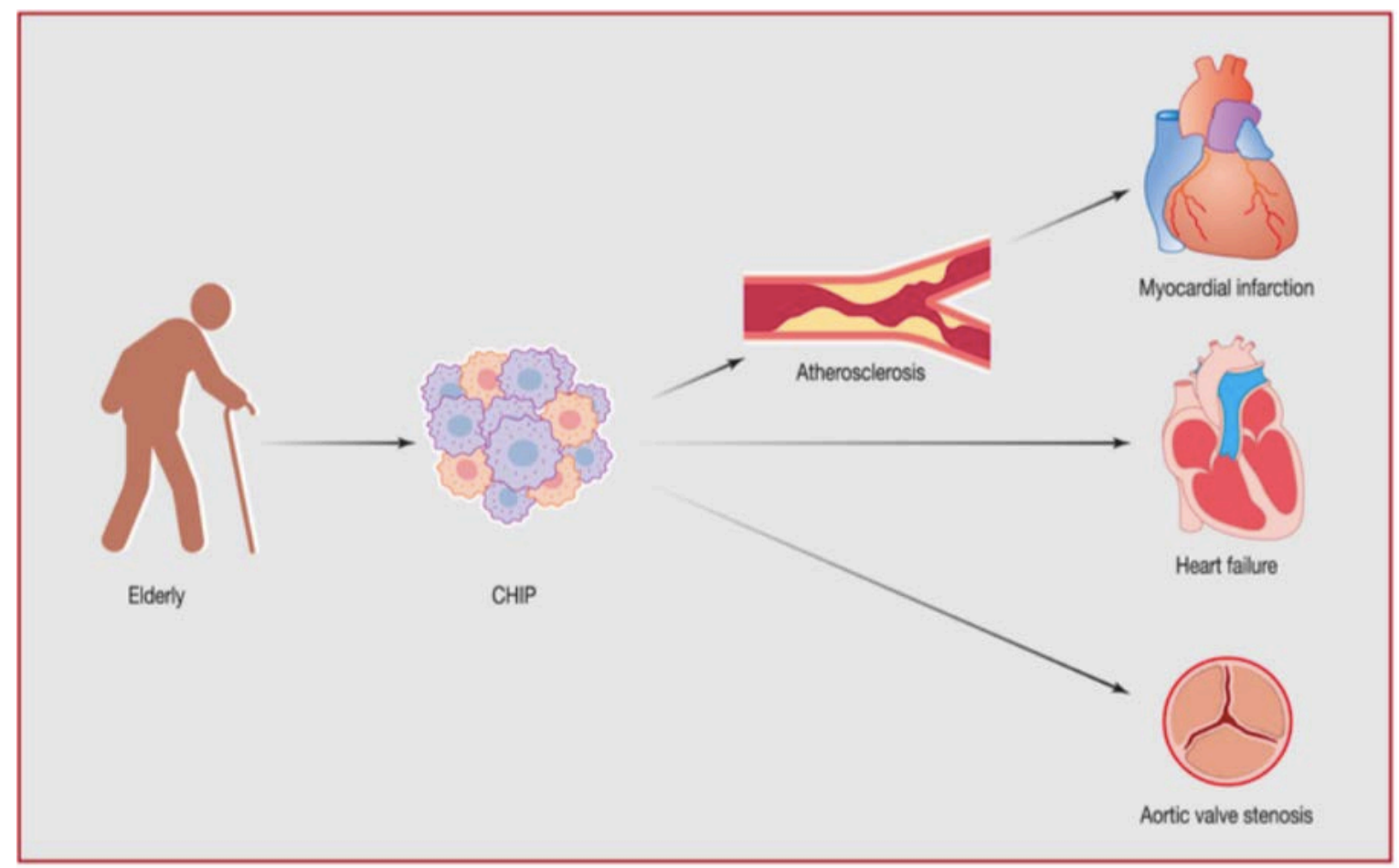

Central illustration. Clonal haematopoiesis of indeterminate potential (CHIP) occurs particularly in the elderly; it is the result of an acquired mutation occurring in a population of haematopoietic stem cells, conferring a growth advantage to their progeny. Because of the proinflammatory phenotype, it favours atherothrombosis, leading to coronary artery diseases such as myocardial infarction, and is also associated with heart failure (ischaemic and non-ischaemic) as well as aortic stenosis, altering the prognosis of CHIP carriers. 
Table 1 The most commonly mutated genes ${ }^{\mathrm{a}}$ observed in large cohorts of clonal haematopoiesis [5-10].

\begin{tabular}{ll}
\hline Mutated gene & Frequency (\%) \\
\hline DNMT3A (DNA methyltransferase & 49.1 \\
3A) & \\
TET2 (Ten-eleven translocation 2) & 18.9 \\
ASXL1 (Additional sex combs-like 1) & 7.1 \\
PPM1D (Protein phosphatase, & 2.7 \\
Mg ${ }^{2+} / \mathrm{Mn}^{2+}$-dependent 1D) & \\
SF3B1 (Splicing factor 3B subunit 1) & 2.7 \\
TP53 (Tumour protein 53) & 2.5 \\
SRSF2 (Serine/arginine-rich splicing & 2 \\
$\quad$ factor 2) & \\
CBL (Casitas B-lineage lymphoma) & 0.6 \\
GNB1 (Guanine nucleotide-binding & 0.5 \\
$\quad$ protein subunit beta-1) & \\
Other & 14 \\
\hline
\end{tabular}

DNA: deoxyribonucleic acid; Mg: magnesium; Mn: manganese.

a The $J A K 2^{\mathrm{V} 617 \mathrm{~F}}$ mutation was excluded. 


\begin{tabular}{|c|c|c|c|c|c|c|c|}
\hline Study & $\begin{array}{l}\text { Number and } \\
\text { origin of } \\
\text { patients }\end{array}$ & $\begin{array}{l}\text { Main outcome } \\
\text { assessed }\end{array}$ & Main result & $\begin{array}{l}\text { Adjustment } \\
\text { for potential } \\
\text { confounders }\end{array}$ & $\begin{array}{l}\text { Potential } \\
\text { bias/limitations }\end{array}$ & $\begin{array}{l}\text { Main genes } \\
\text { concerned }\end{array}$ & $\begin{array}{l}\text { Weight of CHIP } \\
\text { on the risk of CVD }\end{array}$ \\
\hline $\begin{array}{l}\text { Jaiswal et al., } \\
2014 \text { [6] }\end{array}$ & $\begin{array}{l}15,801 ; \\
\text { international } \\
\text { cohort }\end{array}$ & $\begin{array}{l}\text { Detection of } \\
\text { acquired somatic } \\
\text { mutations in } \\
\text { elderly without } \\
\text { known } \\
\text { haematological } \\
\text { disorders }\end{array}$ & $\begin{array}{l}\text { Increase in frequency } \\
\text { of somatic mutations } \\
\text { with age, from } 5.6 \% \\
\text { between } 60 \text { and } 69 \\
\text { years to } 18.4 \% \text { after } 90 \\
\text { years; increased risk of } \\
\text { death, mainly from } \\
\text { cardiovascular causes }\end{array}$ & Age, sex, T2D & - & $\begin{array}{l}\text { DNMT3A; } \\
\text { TET2; ASXL1 }\end{array}$ & $\begin{array}{l}\mathrm{HR} \text { for } \mathrm{CHD} \text { of } 2.0 \\
(95 \% \mathrm{Cl} 1.2-3.5 ; \\
P<0.02) \text {, higher } \\
\text { than } \\
\text { hypertension } \\
(1.4) \text {, lower than } \\
\text { age ( } 2.4 \text { after } 60 \\
\text { years) and T2D } \\
(3.1) ; \mathrm{HR} \text { for } \\
\text { ischaemic stroke } \\
\text { of } 2.6(95 \% \mathrm{Cl} \\
1.3-4.8 ; \\
P<0.003)\end{array}$ \\
\hline $\begin{array}{l}\text { Genovese } \\
\text { et al., } 2014 \\
\text { [5] }\end{array}$ & $\begin{array}{l}\text { 12,380; } \\
\text { Sweden }\end{array}$ & $\begin{array}{l}\text { Detection of } \\
\text { clonal expansion } \\
\text { and somatic } \\
\text { mutations in } \\
\text { healthy people; } \\
\text { analyses of } \\
\text { subsequent } \\
\text { medical } \\
\text { outcomes }\end{array}$ & $\begin{array}{l}\text { Increase in frequency } \\
\text { of somatic mutations } \\
\text { with age, with } 10.4 \% \text { of } \\
\text { people aged }>65 \text { years } \\
\text { being affected; } \\
\text { increased risk of cancer } \\
\text { and reduced overall } \\
\text { survival }\end{array}$ & Age, sex & - & $\begin{array}{l}\text { DNMT3A; TET2 } \\
\text { ASXL1; PPM1D }\end{array}$ & - \\
\hline $\begin{array}{l}\text { Jaiswal et al., } \\
2017 \text { [9] }\end{array}$ & $\begin{array}{l}8255 \text {; } \\
\text { international } \\
\text { cohort }\end{array}$ & $\begin{array}{l}\text { Testing the } \\
\text { hypothesis that } \\
\text { CHIP increases } \\
\text { the risk of } \\
\text { atherosclerotic } \\
\text { CVD }\end{array}$ & $\begin{array}{l}\text { Increased risk of CHD } \\
\text { (HR 1.9, 95\% CI } \\
1.4-2.7 ; P<0.001) \text { and } \\
\text { early-onset } \mathrm{MI}(\mathrm{HR} 4.0 \text {, } \\
95 \% \mathrm{Cl} 2.4-6.7 ; \\
P<0.001)\end{array}$ & $\begin{array}{l}\text { Age, sex, T2D, } \\
\text { smoking } \\
\text { status, } \\
\text { hypercholes- } \\
\text { terolaemia, } \\
\text { hypertension }\end{array}$ & $\begin{array}{l}\text { Case-control } \\
\text { study }\end{array}$ & $\begin{array}{l}\text { DNMT3A; } \\
\text { TET2; ASXL1 }\end{array}$ & $\begin{array}{l}\text { Higher HR for } \\
\text { CHD than for age } \\
(1.0) \text {, smoking } \\
\text { status (1.04) or } \\
\text { diabetes (0.9); } \\
\text { slightly lower HR } \\
\text { for CHD than for } \\
\text { hypertension } \\
\text { (2.01) }\end{array}$ \\
\hline
\end{tabular}


Table 2 (Continued)

\begin{tabular}{|c|c|c|c|c|c|c|c|}
\hline Study & $\begin{array}{l}\text { Number and } \\
\text { origin of } \\
\text { patients }\end{array}$ & $\begin{array}{l}\text { Main outcome } \\
\text { assessed }\end{array}$ & Main result & $\begin{array}{l}\text { Adjustment } \\
\text { for potential } \\
\text { confounders }\end{array}$ & $\begin{array}{l}\text { Potential } \\
\text { bias/limitations }\end{array}$ & $\begin{array}{l}\text { Main genes } \\
\text { concerned }\end{array}$ & $\begin{array}{l}\text { Weight of CHIP } \\
\text { on the risk of CVD }\end{array}$ \\
\hline $\begin{array}{l}\text { Mas-Peiro } \\
\text { et al., } 2018 \\
\text { [13] }\end{array}$ & 279; Germany & $\begin{array}{l}\text { Assessment of } \\
\text { prevalence and } \\
\text { prognostic value } \\
\text { of DNMT3A and } \\
T E T 2 \text { mutation in } \\
\text { patients } \\
\text { undergoing TAVI }\end{array}$ & $\begin{array}{l}\text { 33.3\% of patients } \\
\text { undergoing TAVI had } \\
\text { CHIP; increased deaths } \\
\text { following TAVI }\end{array}$ & $\begin{array}{l}\text { Age, sex, } \\
\text { NT-proBNP }\end{array}$ & Monocentric & DNMT3A; TET2 & $\begin{array}{l}\text { HR for death } \\
\text { after TAVI of } 4.81 \\
(95 \% \mathrm{Cl} \\
1.49-15.57 \\
P=0.009)\end{array}$ \\
\hline $\begin{array}{l}\text { Dorsheimer } \\
\text { et al., } 2019 \\
\text { [11] }\end{array}$ & 200; Germany & $\begin{array}{l}\text { Assessment of } \\
\text { prevalence and } \\
\text { prognostic value } \\
\text { of CHIP in } \\
\text { patients with } \\
\text { chronic ischaemic } \\
\text { heart failure }\end{array}$ & $\begin{array}{l}18.5 \% \text { of patients with } \\
\text { chronic heart failure } \\
\text { had CHIP; increased } \\
\text { risk of death (HR } 2.11 \text {, } \\
95 \% \mathrm{CI} 1.05-4.24 \text {; } \\
P=0.04 \text { ) and } \\
\text { hospitalisation for } \\
\text { heart failure (HR } 2.09 \text {, } \\
95 \% \mathrm{Cl} 1.10-3.95 \text {; } \\
P=0.02 \text { ) }\end{array}$ & $\begin{array}{l}\text { Age, } \\
\text { hypertension }\end{array}$ & Monocentric & DNMT3A; TET2 & $\begin{array}{l}\text { Higher HR for } \\
\text { death and } \\
\text { hospitalisation } \\
\text { than for age } \\
\text { ( } 1.04 \text { and } 1.04 \text {, } \\
\text { respectively) or } \\
\text { hypertension } \\
(0.70 \text { and } 0.95 \text {, } \\
\text { respectively) }\end{array}$ \\
\hline
\end{tabular}

CHD: coronary heart disease; CHIP: clonal haematopoiesis of indeterminate potential; Cl: confidence interval; CVD: cardiovascular disease; HR: hazard ratio; MI: myocardial infarction; NT-proBNP: N-terminal prohormone of brain natriuretic peptide; TAVI: transcatheter aortic valve replacement; T2D: type 2 diabetes. 